\title{
Evaluation of Factors Affecting Uricase Production by the Screened Wild/Natural Microbes
}

\author{
HARINATH DWIVEDI ${ }^{1}$, KUSUM AGRAWAL $^{2}$, AND SHUBHINI A. SARAF $^{3}$ \\ ${ }^{1}$ School of Pharmaceutics, Faculty of Pharmacy, Babu Banarasi Das University, Lucknow \\ (Uttar Pradesh), India \\ ${ }^{2}$ School of Biotechnology, Shobhit University, Meerut (Uttar Pradesh), India \\ ${ }^{3}$ Babasaheb Bhimrao Ambedkar University, Lucknow (Uttar Pradesh), India \\ shubhini.saraf@gmail.com
}

Received 15 November 2011; Accepted 16 January 2012

\begin{abstract}
Gout is a metabolic disorder due to the deposition of uric acid crystals within articular or periarticular tissues. Uricase (urate oxidase) catalyzes the oxidation of less water soluble uric acid $(7 \mathrm{mg} / \mathrm{dl})$ to a compound allantoin which is more water soluble $\left(11 \mathrm{~g} / \mathrm{L}\right.$ at $\left.40^{\circ} \mathrm{C}\right)$ resulting into the ease of excretion of uric acid. The objective of the work was to develop a new method for screening of microbes for uricase production and estimation of uricase thereof. This was achieved by utilizing the fact that uric acid dissolves on being acted upon by uricase. The proposed method is a novel, inexpensive, simple and sensitive technique for screening and estimation of uricase. Biomass and uricase production at different stages of microbial growth curve for the uricase producing microbe was studied. Effects of different medium components affecting uricase production by microbes were studied using Placket Burman statistical design. Addition of uric acid in the nutrient medium was found to be effective in increasing the uricase production by microbes growing in the medium.
\end{abstract}

Key words: Uricase, Uricase estimation, enzyme estimation, Uricase plate assay method, Uricase Production.

\section{Introduction}

Enzymes are biocatalysts, thermo labile in nature and highly specific molecules for their action on substrate. These enzymes are synthesized by living cells only ${ }^{1 .}$ Uricase is an enzyme which can be synthesized by several wild microbes ${ }^{2}$. Identification of natural microbes which produce uricase is a difficult task, because it requires each microbial colony to be tested for the presence of uricase, by using estimation kits available in the market. These have a high cost and require specific critical environmental conditions for conduction of the tests. Uric acid is a weak acid which has a maximum solubility of $7 \mathrm{mg} / \mathrm{dL}$ in plasma. Normal plasma urate levels are between 3.3 to $6.9 \mathrm{mg} / \mathrm{dl}$. Uric acid is degraded by urate oxidase (uricase) to allantoin as described previously,4,5. Allantoin has a much higher solubility which is $400 \mathrm{mg} / \mathrm{dl}$ in plasma and water at $25^{\circ} \mathrm{C}$. 
Estimation of enzyme activity in body fluids is an old concept which has often been utilized as an aid to diagnosis. Uricase is widely used to monitor serum uric acid for laboratory diagnosis of gout, kidney function and hyperuricemia-associated diseases as described previously ${ }^{6,7}$. Elitek $\mathrm{T}^{\mathrm{M}}$ is the available intravenous dosage form of uricase manufactured by Sanofi Aventis and Elitek International Corporation. Uricase can be estimated by quantifying uric acid by its distinctive absorbance at $293 \mathrm{~nm}$ or by quantifying hydrogen peroxide, one of the uricase products, by peroxidase-coupled analysis ${ }^{8}$.

Placket-Burman Design was used to estimate the effect of different nutrient components. More than five independent variables can be investigated by this technique to find out the most important variable in a system. This technique allows the evaluation of X-1 variables by $\mathrm{X}$ experiments where $\mathrm{X}$ must be a multiple of 4 .

\section{Materials and Methods}

\section{Screening of Uricase Producing Soil Microbes}

Microbes obtained from a soil samples were cultured in the LB (Luria Bertani) nutrient broth medium which contains $10.0 \mathrm{~g}$ Beef extract, $10.0 \mathrm{~g}$ Peptone, $5 \mathrm{mg}$ Sodium Chloride in $1000.0 \mathrm{ml}$ of distilled water (Brown 2001). Different microbes were isolated using spread plate method. Isolated individual colonies were grown in LB nutrient broth medium (pH 7.5) at $37^{\circ} \mathrm{C}$. For sub-culturing, the isolated microbes at a concentration of $5.0 \% \mathrm{v} / \mathrm{v}$ of inoculum , at the stage of 0.8 optical density and $600 \mathrm{~nm}$ of wavelength of light, were inoculated into already sterilized $25 \mathrm{ml} \mathrm{LB}$ nutrient broth medium $(\mathrm{pH} 7.5)$ in a conical flask. The inoculated nutrient broth was incubated at $37^{\circ} \mathrm{C}$ for 48 hours, in a conical flask. At the end of incubation period, $50 \mu \mathrm{l}$ of microbial culture was filled in a well, formed in a solidified $2.0 \% \mathrm{w} / \mathrm{v}$ agar medium in water, containing $0.5 \% \mathrm{w} / \mathrm{v}$ uric acid, inside a petriplate. Sterilized nutrient broth medium was used as a control in a separate well. The plate was incubated at $37^{\circ} \mathrm{C}$ for 24 hours. The term, Zone of clearance was coined for the clear zone which developed due to degradation of uric acid because of the presence of uricase in the agar well. This method is henceforth referred to as the uricase plate assay method. Zone of clearance developed around the wells for each microbial sample was measured and production of uricase enzyme by the microbe was identified. The production of uricase enzyme by the microbes was confirmed by quantitative estimation performed with the help of Amplex Red Uric acid/Uricase assay kit (A22181) procured from Molecular Probes Invitrogen Detection Technologies, USA.

\section{Quantitative Estimation of Uricase Enzyme by Enzyme Assay Kit}

Quantitative estimation of the uricase produced was also done by Amplex Red uric acid/uricase assay kit (A22181) The Amplex red uricase assay kit provides an ultrasensitive method for detecting uricase activity. In the assay, uricase catalyzes the conversion of uric acid to allantoin, hydrogen peroxide and carbon dioxide. The $\mathrm{H}_{2} \mathrm{O}_{2}$ in presence of horseradish peroxidase (HRP) reacts stoichiometrically with Amplex Red reagent to generate the red fluorescent oxidation product, resorufin. Resorufin gives maximum absorbance at its lambda max $560 \mathrm{~nm}$.

\section{Procedure for Quantitative Estimation of Uricase by Assay Kit}

\section{Preparation of Standard Graph}

Five dilutions of uricase were prepared (5 m Unit/ml, $10 \mathrm{~m} \mathrm{Unit} / \mathrm{ml}, 15 \mathrm{~m} \mathrm{Unit} / \mathrm{ml}, 20 \mathrm{~m}$ Unit $/ \mathrm{ml}$ and $25 \mathrm{~m} \mathrm{Unit} / \mathrm{ml}$ ). A volume of $50 \mu 1$ of each dilution was added in separate wells of 96 well ELISA plate. Reaction buffer of 1x provided with the kit was used to dilute the 
standard uricase enzyme solution. A volume of $50 \mu \mathrm{l}$ of working solution which contains amplex red reagent, HRP (Horse radish peroxidase) solution, $5 \mathrm{mM}$ uric acid solution and $1 \mathrm{x}$ reaction buffer was added in the respective wells. The plate was incubated at $37^{\circ} \mathrm{C}$ temperature for duration of 30 minutes. After incubation the optical absorbance for the standard solutions were recorded by ELISA micro plate reader at $560 \mathrm{~nm}$. Absorbance was recorded and a graph plotted between absorbance and concentration for uricase (Fig.1).

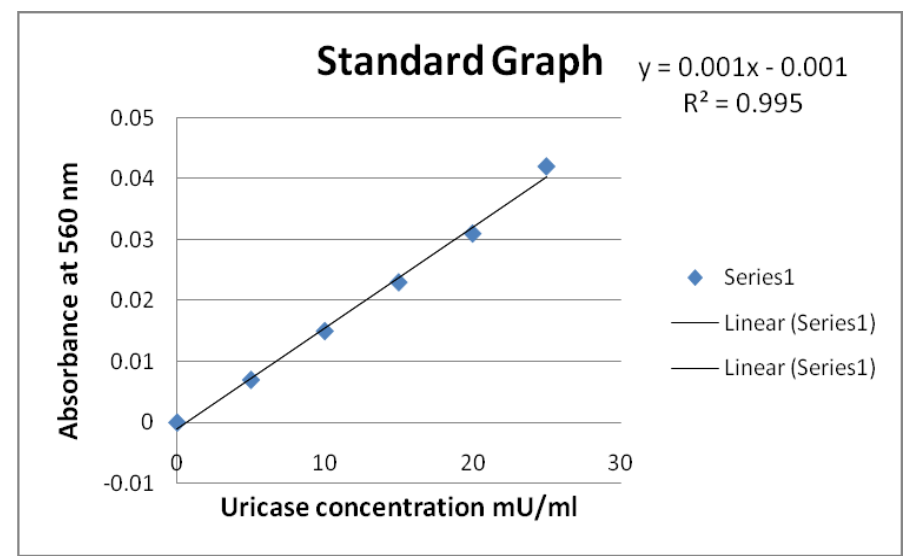

Figure 1. Standard graph for uricase estimation (1x reaction buffer $\mathrm{pH} 7.5)$.

\section{Quantitative Estimation of Uricase by Plate Assay Method}

\section{Procedure for Uricase Plate Assay Method}

A $25 \mathrm{ml}$ agar solution $(2 \% \mathrm{w} / \mathrm{v})$ was prepared in distilled water by addition of slow heat. The solution was boiled to get a clear solution. The solution was allowed to cool up to about $45^{\circ} \mathrm{C}$. At this temperature, when the agar solution remains in a liquid condition, $0.5 \% \mathrm{w} / \mathrm{v}$ uric acid and a small amount of safranin dye was added to it with proper mixing. Uric acid degrades above $60^{\circ} \mathrm{C}$ hence it should be added only after cooling.

When uricase containing different samples were estimated for the amount of uricase by the proposed uricase plate assay method the diameter of zone of clearance developed were found to be the directly proportional to the logarithmic concentration of the uricase added in the well.

The sample containing uricase, when added in the well formed inside the solidified agar, converts the suspended uric acid into clear water soluble allantoin, which develops a clear zone around the well. The samples which do not have uricase, fail to develop a zone of clearance. The diameter of the zone of clearance developed was found to be more in case of samples containing higher concentrations of uricase. A volume of $50 \mu 1$ of each sample was added in the well formed in the solidified agar $(2 \% \mathrm{w} / \mathrm{v})$ containing suspended uric acid $(0.5$ $\% \mathrm{w} / \mathrm{v}$ ) in a petriplate. The plate was incubated at $37^{\circ} \mathrm{C}$ for a duration of 24 hours. The diameter of zone of clearance developed after the incubation period was measured and was found to be directly proportional to the logarithmic concentration of the sample applied 


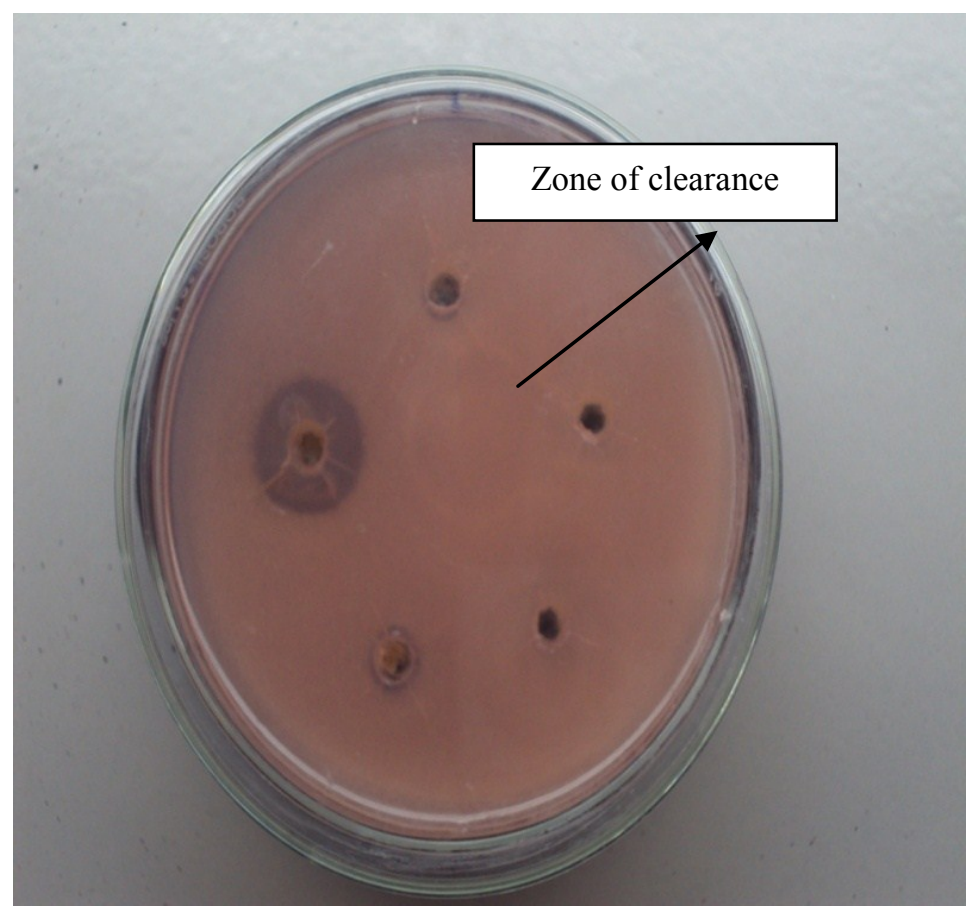

Figure 2. Zone of clearance produced by action of uricase.

The proposed method for the screening the microbes producing uricase, as well as for estimation of the amount of uricase present in the given sample is found to be effective as confirmed by uricase assay kit (Invitrogen Detection Technologies). The proposed enzyme assay method is inexpensive, simple and sensitive to detection and estimation of uricase concentration comparative to several other methods (Laurent et al. 2002; Itiaba 1975; Aoki 1992) from a minimum of $0.5 \mathrm{mU} / \mathrm{ml}$ and higher concentrations.

\section{Preparation of Microbial Growth Curve}

Microbes were allowed to grow in $50 \mathrm{ml}$ sterilized $\mathrm{LB}$ nutrient broth medium at $37^{\circ} \mathrm{C}$ inside a conical flask of $250 \mathrm{ml}$ capacity. To estimate the microbial growth, optical absorbance of microbial culture was measured at $600 \mathrm{~nm}$ wavelength of light at different time intervals using spectrophotometer (UV-1700, Shimadzu Corporation. Kyoto, Japan).

\section{Change in pH during Microbial Growth}

The uricase producing microbes were allowed to grow in $50 \mathrm{ml} \mathrm{LB}$ nutrient broth medium (pH 7.0) at $37^{\circ} \mathrm{C}$ inside a conical flask of $250 \mathrm{ml}$ capacity. Required temperature and suitable atmospheric conditions for microbial growth were generated by using incubator (Sunbeam, DTC-308-2). As the microbes grow the $\mathrm{pH}$ of the culture medium was recorded by the $\mathrm{pH}$ meter (Labtronics, LT-11). 


\section{Estimation of Biomass Production}

When microbes were allowed to grow in LB nutrient broth medium in suitable atmospheric conditions, the biomass production was estimated. A volume of $5 \mathrm{ml}$ of the microbial culture was centrifuged at $8000 \mathrm{rpm}\left(25^{\circ} \mathrm{C}\right)$ in a refrigerated centrifuge for duration of 20 minutes. The supernatant was discarded and pellet was dried at $70^{\circ} \mathrm{C}$ for duration of one hour to obtain the dry cell mass.

\section{Estimation of Uricase Production}

Uricase production was estimated at different time intervals during the microbial growth. A volume of $5 \mathrm{ml} \mathrm{microbial} \mathrm{culture} \mathrm{was} \mathrm{centrifuged} \mathrm{at} 8000 \mathrm{rpm}\left(25^{\circ} \mathrm{C}\right)$ for 20 minute. The supernatant was discarded and the pellet was suspended in $1 \mathrm{ml}$ phosphate buffer $(\mathrm{pH} 7.0)$. The suspended pellet was sonicated using ultra probe sonicator for 20 cycles $(20$ second sonication, 1 minute rest). The sonicated pellet suspension was centrifuged at $8000 \mathrm{rpm}$ $\left(25^{\circ} \mathrm{C}\right)$ for 20 minute. The supernatant was collected and $50 \mu \mathrm{l}$ of this solution was estimated for the amount of uricase in it.

\section{Uricase Production in Presence of Uric Acid in the Medium}

The uricase production in the presence of $0.1 \% \mathrm{w} / \mathrm{v}$ uric acid in the nutrient broth medium was found to be affected by the presence of uric acid in the medium. A volume of $5 \mathrm{ml} 7$ days old microbial culture was centrifuged at $8000 \mathrm{rpm}\left(25^{\circ} \mathrm{C}\right)$ for 20 minute. The supernatant was discarded and the pellet was suspended in $1 \mathrm{ml}$ phosphate buffer ( $\mathrm{pH}$ 7.0). The suspended pellet was sonicated by using ultra probe sonicator for 20 cycles $(20$ second sonication, 1 minute rest). The sonicated pellet suspension was centrifuged at $8000 \mathrm{rpm}$ $\left(25^{\circ} \mathrm{C}\right)$ for 20 minute. The supernatant was collected and $50 \mu \mathrm{l}$ of this solution was estimated for the amount of uricase in it.

\section{Effect of Different Nutrient Components on Production of Uricase}

The LB nutrient broth medium was selected as medium for growth of the uricase producing microbe which was constituted by $10.0 \mathrm{~g}$ beef extract, $10.0 \mathrm{~g}$ Peptone, $5.0 \mathrm{mg}$ Sodium chloride and distilled water sufficient to produce $1000 \mathrm{ml}$.

Beef extract, Peptone, Sodium Chloride, Incubation temperature, Inoculum, Agar and starch were selected as parameters to investigate their effect on Uricase production. Dummy variables help to estimate the errors. Agar and starch were selected as dummy variables for the present Placket - Burman design.

In Placket Burman design each horizontal row represents a trial while each vertical column represents the $\mathrm{H}$ (high) and $\mathrm{L}$ (low) values of one variable in all the trials. This design requires that the frequency of each level of a variable in a given column should be equal and that in each test (horizontal row) should be constant. If there are no interactions and no errors in measuring the response, the effect shown by a dummy variable should be zero. Mean square, mean square for error and effect of each variable was calculated (table 2). 
Table 1. Parameters of Placket Burman design.

\begin{tabular}{|c|c|c|c|c|c|c|c|c|}
\hline Trial & $\begin{array}{c}\text { A } \\
\text { Beef } \\
\text { extract }\end{array}$ & $\begin{array}{c}\text { B } \\
\text { Peptone }\end{array}$ & $\begin{array}{c}\text { C } \\
\text { Sodium } \\
\text { chloride }\end{array}$ & $\begin{array}{c}\text { D } \\
\text { Temperature }\end{array}$ & $\begin{array}{c}\text { E } \\
\text { Inoculum }\end{array}$ & $\begin{array}{c}\text { F } \\
\text { Agar }\end{array}$ & $\begin{array}{c}\text { G } \\
\text { Starch }\end{array}$ & $\begin{array}{c}\text { Yield } \\
\text { IU/ml }\end{array}$ \\
\hline 1 & H & H & H & L & H & L & L & 7.0 \\
\hline 2 & L & H & H & H & L & H & L & 6.0 \\
\hline 3 & L & L & H & H & H & L & H & 4.0 \\
\hline 4 & H & L & L & H & H & H & L & 5.0 \\
\hline 5 & L & H & L & L & H & H & H & 5.0 \\
\hline 6 & H & L & H & L & L & H & H & 4.0 \\
\hline 7 & H & H & L & H & L & L & H & 8.0 \\
\hline 8 & L & L & L & L & L & L & L & 3.0 \\
\hline
\end{tabular}

Key : $\mathrm{L}=$ low level, $\mathrm{H}=$ high level., A levels $(\mathrm{L}=8.0 \mathrm{~g} / \mathrm{l}, \mathrm{H}=12 \mathrm{~g} / \mathrm{l})$, B levels $(\mathrm{L}=8.0 \mathrm{~g} / \mathrm{l}, \mathrm{H}=$ $12 \mathrm{~g} / \mathrm{l})$, C levels $\left((\mathrm{L}=3.0 \mathrm{mg} / \mathrm{l}, \mathrm{H}=12 \mathrm{mg} / \mathrm{l})\right.$, D levels $\left(\mathrm{L}=30^{\circ} \mathrm{C}, \mathrm{H}=38^{\circ} \mathrm{C}\right)$, E levels $(\mathrm{L}=$ $3 \%, \mathrm{H}=7 \%)$, F levels $(\mathrm{L}=0.1 \% \mathrm{w} / \mathrm{v}, \mathrm{H}$ levels $0.2 \% \mathrm{w} / \mathrm{v})$, G levels $(\mathrm{L}=0.1 \% \mathrm{w} / \mathrm{v}, \mathrm{H}=$ $0.2 \% \mathrm{w} / \mathrm{v})$.

Table 2. Statistical evaluation of process parameters by Placket Burman design.

\begin{tabular}{|l|c|c|c|c|c|c|c|}
\hline & \multicolumn{7}{|c|}{ Factors } \\
\hline & $\mathrm{A}$ & $\mathrm{B}$ & $\mathrm{C}$ & $\mathrm{D}$ & $\mathrm{E}$ & $\mathrm{F}$ & $\mathrm{G}$ \\
\hline$\sum(\mathrm{H})$ & 24.0 & 26.0 & 21.0 & 23.0 & 21.0 & 20.0 & 21.0 \\
\hline$\sum(\mathrm{L})$ & 18.0 & 16.0 & 21.0 & 19.0 & 21.0 & 22.0 & 21.0 \\
\hline Difference & 6.0 & 10.0 & 0.0 & 4.0 & 0.0 & -2.0 & 0.0 \\
\hline Variance & 1.5 & 2.5 & 0.0 & 1.0 & 0.0 & -0.5 & 0.0 \\
\hline $\begin{array}{l}\text { Mean } \\
\text { square }\end{array}$ & 4.5 & 12.5 & 0.0 & 2.0 & 0.0 & 0.03 & 0.0 \\
\hline \begin{tabular}{l} 
Effect \\
\hline
\end{tabular} & 288.0 & 800.0 & 0.0 & 128.0 & 0.0 & 2.0 & 0.0 \\
\hline
\end{tabular}

\section{Results and Discussion}

An attempt was made to correlate the fact that uric acid has a solubility of $7 \mathrm{mg} / \mathrm{dL}$ in water while allantoin is more soluble than uric acid having a solubility of $400 \mathrm{mg} / \mathrm{dL}$ and that allantoin is formed when uricase acts upon uric acid ${ }^{3}$. Utilizing this as the basis, a novel, simple and inexpensive method for estimation of uricase was developed. In the method, a sample containing uricase when added to a well formed in the solidified agar converts the suspended uric acid into clear and water soluble product allantoin, thereby developing a clear zone around the well. Uric acid is known to degrade above $60^{\circ} \mathrm{C}$, thus care was taken to add it only after the medium cooled down to $45^{0} \mathrm{C}$. The samples which do not have uricase, fail to develop a zone of clearance. The diameter of the zone of clearance developed 
was found to be directly proportional to the logarithmic concentration of uricase. Addition of a small amount of safranin dye in the medium in which wells are formed, gives a better contrast between zone of clearance developed and rest of the medium resulting in better visualization.

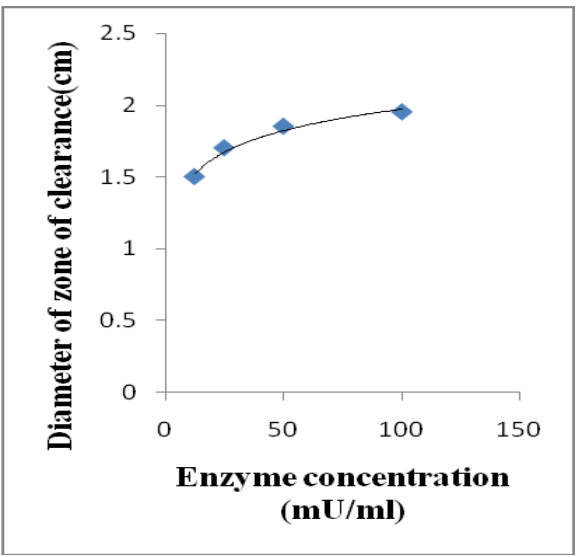

(a)

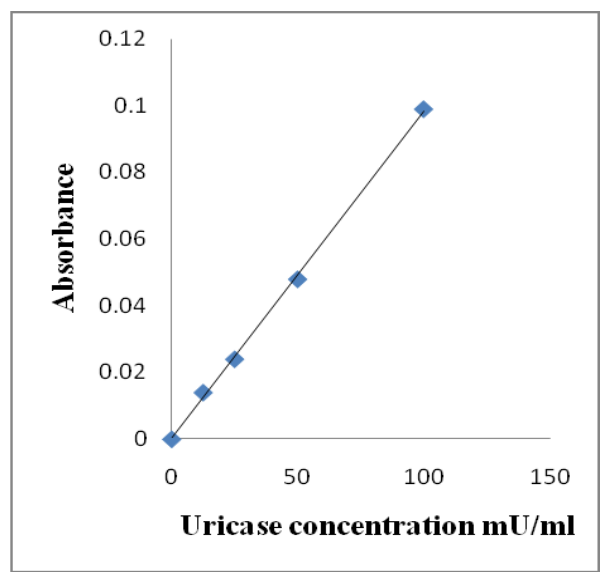

(b)

Figure 3. (a) Graph indicating the relationship between the enzyme concentration and (a) diameter of the zone of clearance developed, (b) optical absorbance at $560 \mathrm{~nm}$ wavelength of light.

Microbial growth curve was plotted for a bacterial strain with good uricase producing ability when it was inoculated into LB nutrient broth medium and was incubated in the suitable atmospheric condition. Growth curve indicates that incubated strain has a lag phase of about 4.0 hours while it enters into the stationary phase after 16 hours followed by log phase in between. Uricase production was found to be started during stationary phase.

The $\mathrm{pH}$ of the medium was found to be continuously decreasing during microbial growth. Decrease in $\mathrm{pH}$ may be due to the accumulation of lactic acid, glutamic acid or other acidic components during the microbial growth. Addition of alkali $(4 \mathrm{~N} \mathrm{NaOH})$ ensured the enlargement of the log phase (Fig.6).

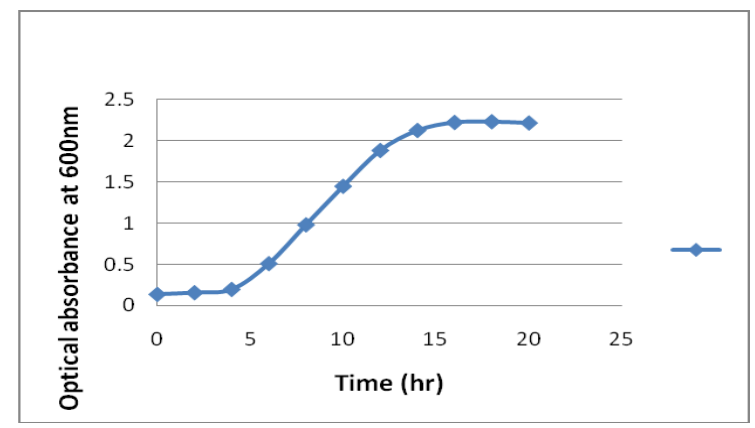

Figure 4. Growth curve for uricase producing microbes. 


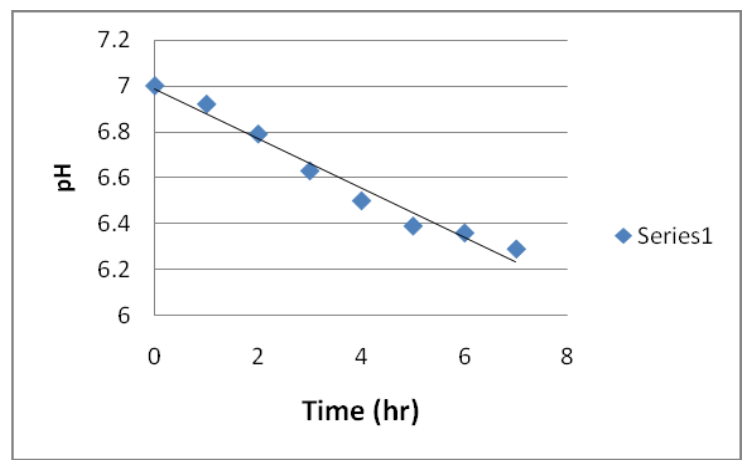

Figure 5. Change in $\mathrm{pH}$ at different time intervals during microbial growth.

Biomass production was estimated at different time intervals during microbial growth. A very little Biomass production was observed during first four hours while a constant rate of Biomass production was observed during lag phase. After 20 hours of microbial growth the Biomass production was found to be almost constant indicating the start of the stationary phase.

First time uricase production by microbes was observed after 20 hours of microbial growth during stationary phase. Uricase production was found to be increasing even upto 5 days old microbial culture, later on it becomes constant and starts decreasing when microbial culture becomes older than seven days (Fig.8.).

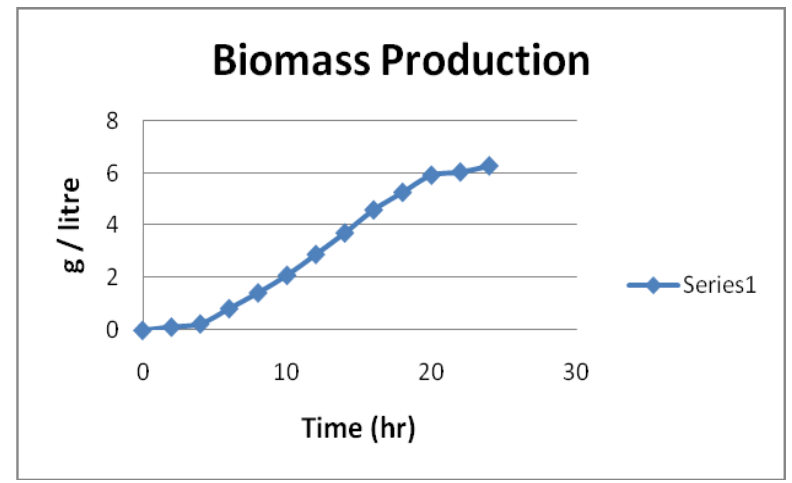

Figure 6. Biomass production at different time intervals.

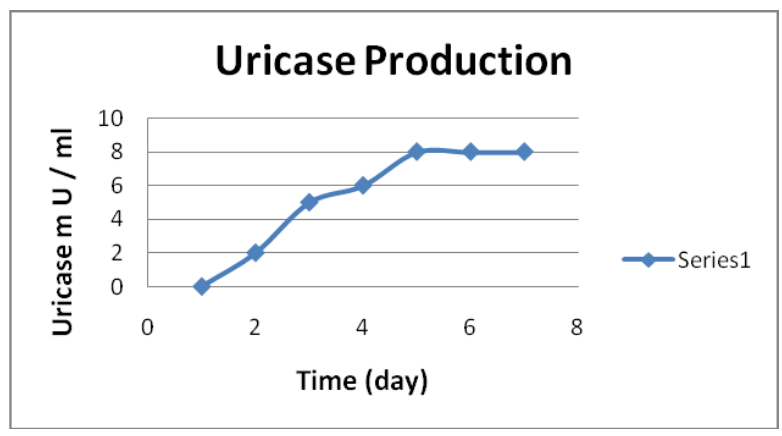

Figure 7. Uricase production during microbial growth. 
Uricase production was found to be increased up to $14 \mathrm{mU} / \mathrm{ml}$ in presence of uric acid in the ntrient medium. Presence of uric acid in the medium ensured the earlier and higher level of uricase production by the microbes (Fig.9 and 10).

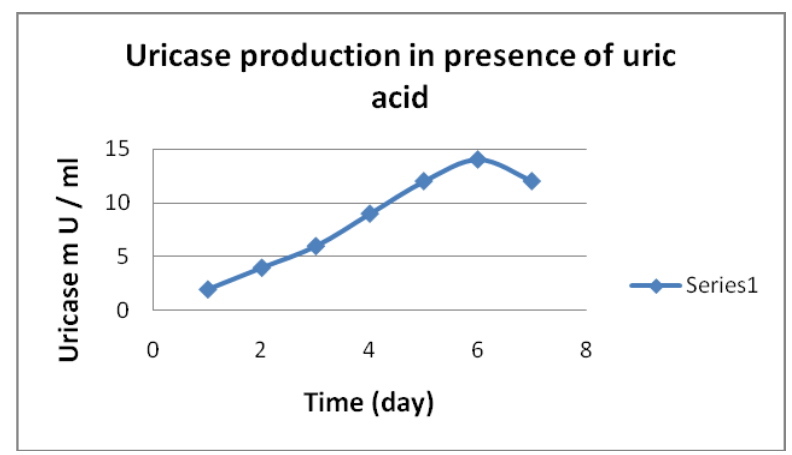

Figure 8. Production of uricase at different time intervals when uric acid was present in the medium.

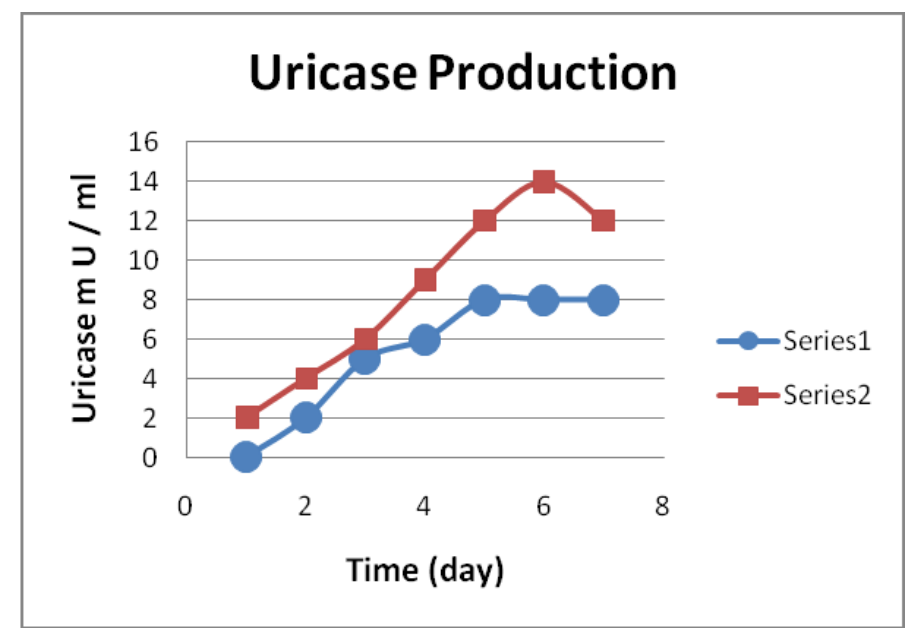

Figure 9. Comparison of uric acid production in presence and absence of uric acid (series- 1 in absence of uric acid, series 2-in presence of uric acid).

Different parameters affecting uricase production were statistically evaluated with the use of Placket-Burman design. On the basis of statistical analysis effect of peptone was found to be the maximum for Uricase production followed by beef extract and incubation temperature. Effect of sodium chloride in the medium and percentage of inoculums taken for microbial culture were found to be ineffective for Uricase production by microbes.

\section{Conclusion}

Uricase producing microbes were easily screened by novel Uricase plate assay method. Different parameters affecting Uricase production by microbes were estimated using Placket- Burman statistical design which revealed that peptone, beef extract and incubation temperature are the key parameters affecting uricase production while presence of sodium chloride in the medium and percentage of inoculums taken for microbial culture are the parameters which least affect Uricase production by the screened microbes. 


\section{References}

1. Alexander So, Arthritis Research \& Therapy 2008, 10 (5), 221-226.

2. Aoki Y, Ihara H, Nakamura H, Aoki T, Yoshlda M, Clin Chem., 1992, 38(7), 13501352

3. Bartl K, Brandhuber M, Ziegenhorn J, Clin Chem., 1979, 25(4), 619-621.

4. Brown TA, Gene cloning and DNA analysis An introduction, $4^{\text {th }}$ ed,; Blackwell Science Ltd, Gosport Great Britain, 29-30.

5. Cammalleri L, Malaguarnera M, International Journal of Medical Sciences, 2007, $4(2), 83-93$.

6. Donald V, Judith G, Charlotte W, Fundamentals of Biochemistry, John Wiley \& Sons, New York, 1999, 281-321.

7. Duncan P H, Gochman N, Cooper T, Smith E, Bayse D, Clin Chem., 1982, 28(2), 284290.

8. Itiaba K, Hsiung M W, Crawhall J C, Clinical Biochemistry, 1975, 8, 316 - 319.

9. Dwivedi H, Agrawal K, Saraf S A, International Journal of Pharmacy and Pharmaceutical Sciences, 2012, 4(1), 422-424.

10. Laurent F, Marie C B, Jacques P F, Christophe A D, Alain B, Analytical Biochemistry, 309(2), 173-179.

11. Liao F, Zhao Y, Zhao L, Tao J, Zhu X, Liu L, J Zhejiang Univ Sci B, 2006, 7(6): 497502.

12. Richard J J, Yuri Y S, William J O, Carlos R, Wei M, Gabriela S L, Bernardo R, Takahiko N, Steven A B, J Comp Physiol B, 2009, 179(1), 67-76.

13. Xue-lai Z, Xiao-hang M, Gui-qin S, Xia L, Kang-ping G, College of Life Science, Zhejiang University, 2005, Hangzhou 310029, China Shaoxing People's Hospital, Shaoxing 312000, China. 


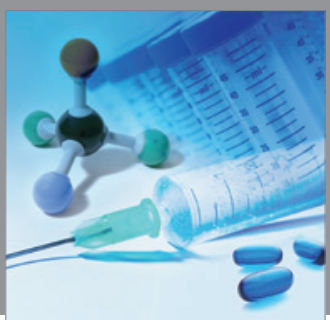

International Journal of

Medicinal Chemistry

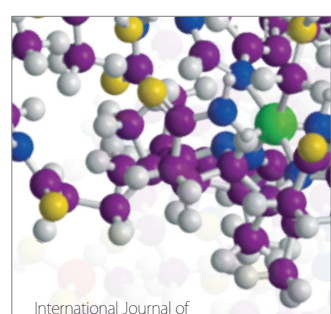

Carbohydrate Chemistry

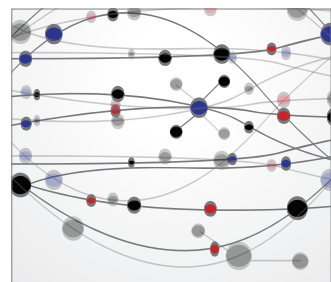

The Scientific World Journal
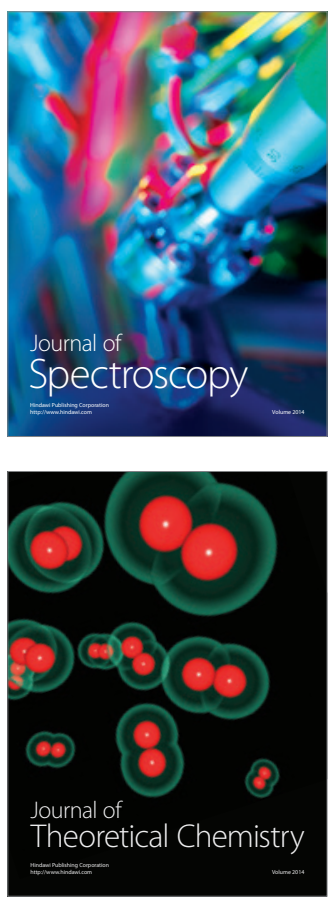
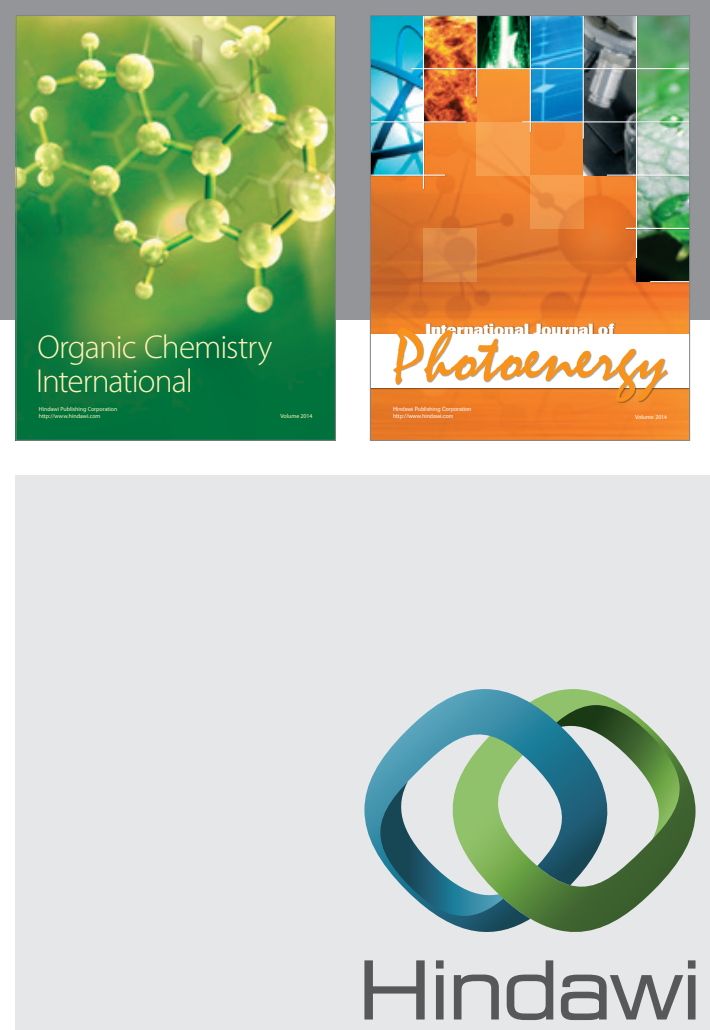

Submit your manuscripts at

http://www.hindawi.com
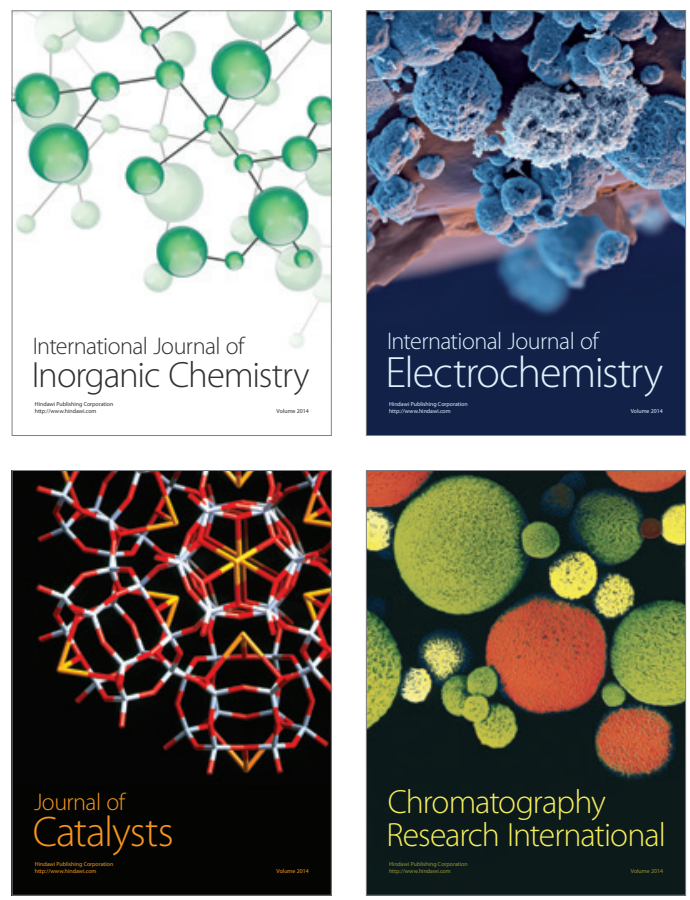
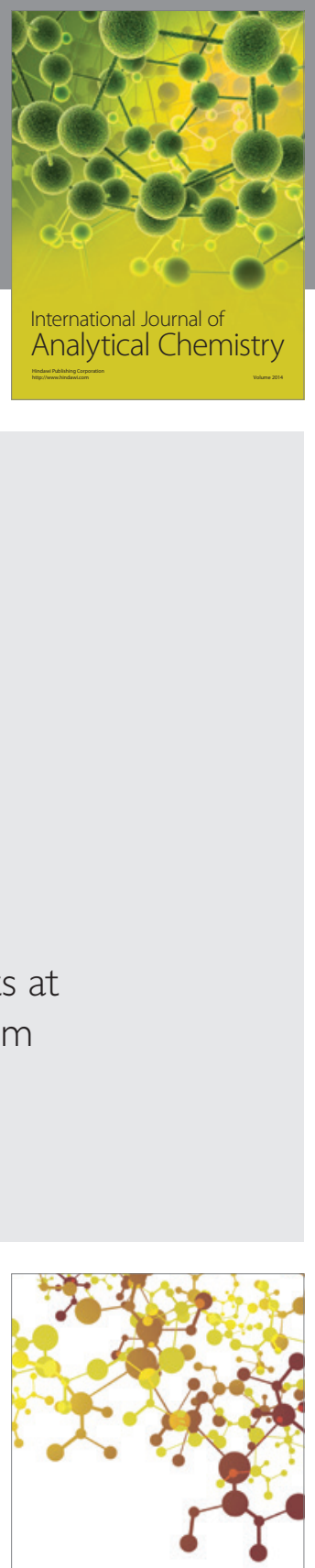

Journal of

Applied Chemistry
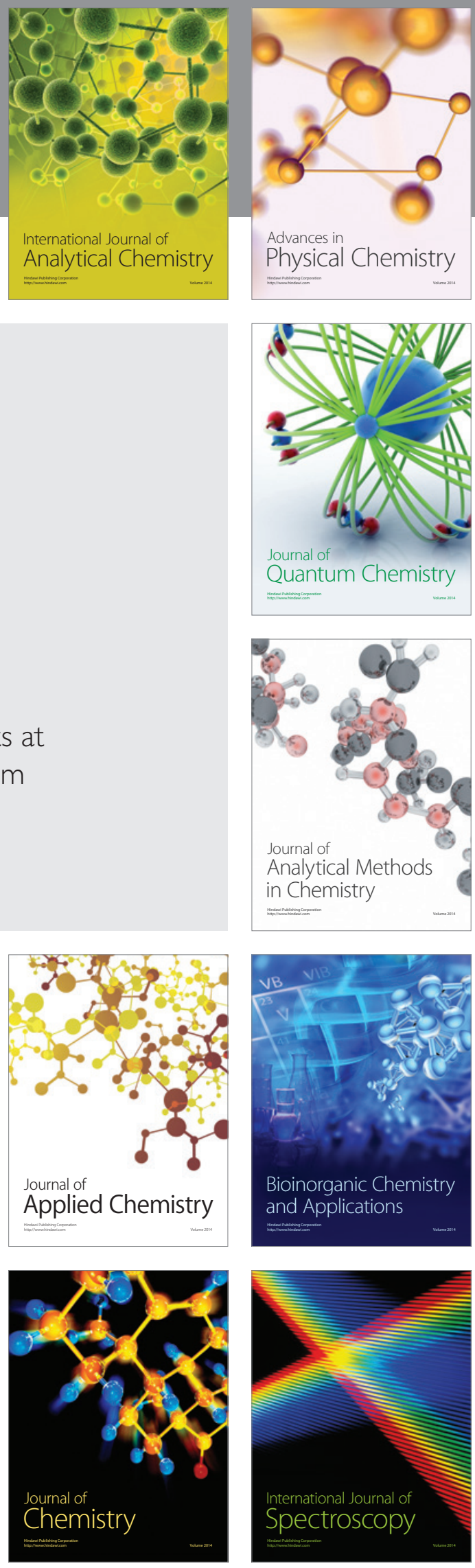